\title{
MicroRNA-mediated regulation of KRAS in cancer
}

\author{
Minlee Kim ${ }^{1,2}$ and Frank J Slack ${ }^{2 *}$
}

\begin{abstract}
While microRNAs (miRNAs) and the KRAS oncogene are known to be dysregulated in various cancers, little is known about the role of miRNAs in the regulation of KRAS in cancer. Here we review a selection of studies published in 2014 that have contributed to our understanding of the molecular mechanisms of KRAS regulation by miRNAs and the clinical relevance of sequence variants that may interfere with functional miRNA-mediated KRAS regulation.
\end{abstract}

Keywords: microRNA (miRNA), KRAS, Cancer, Sequence variant, Single nucleotide polymorphism (SNP), KRAS-variant, rs61764370, rs712

\section{Background}

Since their discovery about two decades ago, the profound role of microRNAs (miRNAs) in various aspects of cancer is being uncovered including in cancer therapy $[1,2]$. MiRNAs modulate a wide range of biological processes, such as cellular proliferation, differentiation and apoptosis, canonically by binding to the 3' UTR of mRNAs by partial complementarity and inhibiting mRNA stability and translation. Since oncogenic KRAS is frequently found in many cancers, including colon, pancreatic, and lung cancer, and different cancer types and stages exhibit distinctive miRNA profiles, the regulation of KRAS by miRNAs has drawn attention in the field. The KRAS oncogene, which encodes a GTPase signaling protein, is a key driver of complex, multistep tumorigenesis, as alteration and activation of the gene and its pathway lead to acquisition of cancerous properties [3].

Here we review the studies published in 2014 that explored miRNA-mediated regulation of KRAS in different cancers. We briefly discuss the tumor-suppressive role of miRNAs that target and regulate KRAS and the regulation of those miRNAs (Table 1). In addition, the clinical potential of sequence variants in the $3^{\prime}$ UTR of KRAS (Table 2) as a cancer biomarker by altering the function of miRNAs is discussed.

MiRNAs that target and regulate KRAS act as tumor suppressors The seminal study by Johnson et al. identified the let-7 family of miRNAs as the first tumor-suppressive miRNA

\footnotetext{
* Correspondence: fslack@bidmc.harvard.edu

${ }^{2}$ Department of Pathology, Beth Israel Deaconess Medical Center, 330 Brookline Ave, Boston, MA 02215, USA

Full list of author information is available at the end of the article
}

known to target and regulate KRAS [4]. Subsequently, other tumor-suppressive miRNAs, including miR-96, miR-30c and miR-181a, have shown to regulate KRAS in various cancers [5-7]. More recently, Gastaldi et al. have utilized a large scale profiling technology, small RNA sequencing, to profile miRNAs in cutaneous squamous cell carcinomas (cSCCs) and identified the miR-193b/365a cluster as one of the most prominently down-regulated miRNAs in murine skin tumor progression [8]. Their role as a tumor suppressor was confirmed in both mouse and human epidermis, as these two miRNAs modulated cellular proliferation, migration and clonogenic potential. Functional assays that showed an inverse relationship between the miRNAs and KRAS protein levels validated that the two miRNAs functioned through targeting KRAS. Additionally, the effects of the miRNAs were recapitulated with KRAS knockdown in squamous carcinoma cells [8].

While several miRNA expression profiles report deregulation of numerous miRNAs in various cancers, only a few miRNAs have been characterized. Liao et al. further investigated the role of miR-30b, one of the known down-regulated miRNAs in colorectal cancer (CRC) [9]. The clinical relevance of miR-30b was shown in a cohort of 91 CRC cases, in which the level of miR-30b was correlated with poor progression and survival. Ectopic expression and inhibition of miR-30b affected cellular proliferation in CRC cell lines and tumor growth in a xenograft mouse model as miR-30b promotes G1 cell-cycle arrest and apoptosis. The effect of miR-30b in tumor growth was mediated through targeting many genes including KRAS [9]. 


\begin{tabular}{|c|c|c|}
\hline miRNA & Cancer type & Reference \\
\hline let-7 & Lung cancer & [4] \\
\hline miR-96 & Pancreatic cancer & [5] \\
\hline miR-30c & Hereditary breast cancer & [6] \\
\hline miR-181a & Oral squamous cell carcinoma & [7] \\
\hline miR-193b/365a & $\begin{array}{l}\text { Cutaneous squamous cell } \\
\text { carcinoma (CSCC) }\end{array}$ & [8] \\
\hline miR-30b & Colorectal cancer (CRC) & {$[9]$} \\
\hline miR-96 & Pancreatic ductal adenocarcinoma (PDAC) & [10] \\
\hline miR-134 & Glioblastoma (GBM) & [11] \\
\hline
\end{tabular}

\section{Regulation of tumor-suppressive miRNAs that modulate KRAS signaling}

As shown in the two above-mentioned studies, as well as many others, many miRNAs have shown to target and regulate KRAS in cancer. However, the mechanisms by which those miRNAs are regulated may lead to a better understanding of cancer development and an opening of new therapeutic approaches. Two recent studies revealed how two KRAS targeting miRNAs are regulated transcriptionally and by other factors in the signaling pathway.

In a cohort of 224 human pancreatic neoplasms, Tanaka et al. reported a widespread overexpression of EVI1 oncogenic transcriptional factor in pancreatic ductal adenocarcinoma (PDAC) precursors and PDAC [10]. The group also uncovered that EVI1 functioned in proliferation and migration in pancreatic cancer cells and can modulate KRAS protein levels and KRAS-ERK pathway by transcriptionally regulating miR-96 and miR-181. Ectopic introduction of miR-96, but not miR-181, decreased KRAS protein expression and resulted in cell cycle arrest in cells, suggesting miR-96 as a tumor suppressor in EVI1-mediated KRAS regulation [10].

Using miRNA microarrays, Zhang et al. found that the MET receptor tyrosine kinase regulated miR-134 in glioblastoma (GBM) cells and glioblastoma stem cells (GSCs) [11]. Additionally, while miR-134 was down-regulated, multiple receptor tyrosine kinases (RTKs), MET, EGFR and PDGFR, were activated in GBM cells, GSCs and human tumors. The tumor-suppressive property of miR-134

Table 2 SNPs in the 3' UTR of KRAS associated with cancer

\begin{tabular}{lll}
\hline SNP ID & Association with cancer & Reference \\
\hline rs61764370 & $\begin{array}{l}\text { Risk of non small-cell lung cancer, epithelial } \\
\text { (KRAS-variant) }\end{array}$ & $\begin{array}{l}\text { ovarian cancer, triple-negative breast cancer, } \\
\text { colorectal cancer. Drug response in } \\
\text { metastatic colorectal cancer }\end{array}$ \\
rs712 & $\begin{array}{l}\text { Risk of oral squamous cell carcinoma, } \\
\text { gastric cancer, colorectal cancer, } \\
\text { papillary thyroid cancer }\end{array}$ & [25-28] \\
\hline
\end{tabular}

was confirmed when overexpression of miR-134 inhibited proliferation in GBM cells and tumor growth in GSCderived xenografts by targeting KRAS and STAT5B. MiR-134 regulation by RTK was mediated by MAPK and KLF4 transcription factor [11].

\section{Sequence variants as potential effectors in miRNA-mediated regulation of KRAS}

In addition to dysregulation of miRNAs, sequence variants in the 3' UTR of target mRNAs can affect their gene regulation. By sequencing the regions of the 3' UTR of KRAS in multiple non-small cell lung cancer (NSCLC) cases, rs61764370 (also known as the KRAS-variant) was identified as the first single nucleotide polymorphism (SNP) within a let-7 complementary site to be a biomarker for NSCLC risk [12]. The KRAS-variant has shown to function as a biomarker for risk of certain cancer types [13-16] and endometriosis [17], as well as a predictor for drug response $[18,19]$. However, the universality of this marker remains to be further investigated as some studies failed to show an association between the KRAS-variant and cancer risk [20,21] and drug response [22]. In addition, two recent studies on the patients enrolled in clinical trials found no association between stage 3 colon cancer and the variant in a large cohort [23], and no significant association between endometrial cancer and the variant due to a limited sample size [24].

Additional sequence variants in the 3' UTR of KRAS have been actively searched for and tested for their potential as biomarkers. While not as extensively validated as the KRAS-variant, another SNP in the 3' UTR of KRAS, the rs712 variant, is being assayed as a biomarker for risk of oral squamous cell carcinoma, gastric, colorectal and papillary thyroid cancer [25-28]. Although no novel NSCLCassociated variant was identified from a recent effort by Kim et al. due to a small sample size [29], this study, as well as a study by Sabarinathan et al. [30] suggested that some SNPs can disrupt proper miRNA-mediated KRAS regulation by destroying miRNA complementary sites and changing the secondary structures of the RNA.

\section{Conclusions and future directions}

Understanding the molecular mechanism of miRNAmediated regulation of KRAS by characterizing tumor suppressive miRNAs and oncoproteins that regulate tumor suppressive miRNAs in the KRAS signaling pathway would be beneficial for developing treatments in the clinic. In addition, the discovery of a validated sequence variant as a cancer biomarker for prognosis, diagnosis and treatment response would provide a valuable clinical tool. For example, many studies are examining the potential of the KRAS-variant as a cancer biomarker. However, the universal clinical relevance of the $K R A S$-variant remains unclear. Since cancer is a very heterogeneous 
disease, and many confounding factors such as population, age and external factors can affect the outcome, rigorous case-control studies are warranted to confirm the clinical application of variants as biomarkers for specific cancers.

\section{Competing interests}

The authors declare that they have no competing interests.

\section{Authors' contributions}

MK and FJS participated in writing and revising of the manuscript. All authors read and approved the final manuscript.

\section{Author details}

${ }^{1}$ Department of Molecular, Cellular and Developmental Biology, Yale University, PO Box 208103, New Haven, CT 06511, USA. ²Department of Pathology, Beth Israel Deaconess Medical Center, 330 Brookline Ave, Boston, MA 02215, USA.

Received: 26 September 2014 Accepted: 6 November 2014

Published online: 30 November 2014

\section{References}

1. Kim M, Kasinski AL, Slack FJ: MicroRNA therapeutics in preclinical cancer models. Lancet Oncol 2011, 12:319-321.

2. Kasinski AL, Slack FJ: Epigenetics and genetics: microRNAs en route to the clinic: progress in validating and targeting microRNAs for cancer therapy. Nature Publishing Group 2011, 11:849-864.

3. Karnoub $A E$, Weinberg RA: Ras oncogenes: split personalities. Nat Rev Mol Cell Biol 2008, 9:517-531.

4. Johnson SM, Großhans H, Shingara J, Byrom M, Jarvis R, Cheng A, Labourier E, Reinert KL, Brown D, Slack FJ: RAS is regulated by the let-7 microRNA family. Cell 2005, 120:635-647.

5. Yu S, Lu Z, Liu C, Meng Y, Ma Y, Zhao W, Liu J, Yu J, Chen J: miRNA-96 suppresses KRAS and functions as a tumor suppressor gene in pancreatic cancer. Cancer Res 2010, 70:6015-6025.

6. Tanic M, Yanowsky K, Rodriguez-Antona C, Andrés R, Márquez-Rodas I, Osorio A, Benitez J, Martinez-Delgado B: Deregulated miRNAs in hereditary breast cancer revealed a role for miR-30c in regulating KRAS oncogene. PLoS One 2012, 7:e38847.

7. Shin K-H, Bae SD, Hong HS, Kim RH, Kang MK, Park N-H: miR-181a shows tumor suppressive effect against oral squamous cell carcinoma cells by downregulating K-ras. Biochem Biophys Res Commun 2011, 404:896-902.

8. Gastaldi C, Bertero T, Xu N, Bourget-Ponzio I, Lebrigand K, Fourre S, Popa A, Cardot-Leccia N, Meneguzzi G, Sonkoly E, Pivarcsi A, Mari B, Barbry P, Ponzio G, Rezzonico R: miR-193b/365a cluster controls progression of epidermal squamous cell carcinoma. Carcinogenesis 2014, 35:1110-1120.

9. Liao W-T, Ye Y-P, Zhang N-J, Li T-T, Wang S-Y, Cui Y-M, Qi L, Wu P, Jiao H-L, Xie Y-J, Zhang C, Wang J-X, Ding Y-Q: MicroRNA-30b functions as a tumour suppressor in human colorectal cancer by targeting KRAS, PIK3CD and BCL2. J Pathol 2014, 232:415-427.

10. Tanaka M, Suzuki HI, Shibahara J, Kunita A, Isagawa T, Yoshimi A, Kurokawa M, Miyazono K, Aburatani H, Ishikawa S, Fukayama M: EVI1 oncogene promotes KRAS pathway through suppression of microRNA-96 in pancreatic carcinogenesis. Oncogene 2014, 33:2454-2463.

11. Zhang Y, Kim J, Mueller AC, Dey B, Yang Y, Lee D-H, Hachmann J, Finderle S, Park DM, Christensen J, Schiff D, Purow B, Dutta A, Abounader R: Multiple receptor tyrosine kinases converge on microRNA-134 to control KRAS, STAT5B, and glioblastoma. Cell Death Differ 2014, 21:720-734.

12. Chin LJ, Ratner E, Leng S, Zhai R, Nallur S, Babar I, Muller R-U, Straka E, Su L, Burki EA, Crowell RE, Patel R, Kulkarni T, Homer R, Zelterman D, Kidd KK, Zhu Y, Christiani DC, Belinsky SA, Slack FJ, Weidhaas JB: A SNP in a let-7 microRNA complementary site in the KRAS 3 ' untranslated region increases non-small cell lung cancer risk. Cancer Res 2008, 68:8535-8540.

13. Cerne J-Z, Stegel V, Gersak K, Novakovic S: KRAS rs61764370 is associated with HER2-overexpressed and poorly-differentiated breast cancer in hormone replacement therapy users: a case control study. BMC Cancer 2012, 12:105.
14. Paranjape $T$, Heneghan $H$, Lindner $R$, Keane FK, Hoffman A, Hollestelle A, Dorairaj J, Geyda K, Pelletier C, Nallur S, Martens JW, Hooning MJ, Kerin M, Zelterman D, Zhu Y, Tuck D, Harris L, Miller N, Slack F, Weidhaas J: A 3'-untranslated region KRAS variant and triple-negative breast cancer: a case-control and genetic analysis. Lancet Oncol 2011, 12:377-386.

15. Ratner E, Lu L, Boeke M, Barnett R, Nallur S, Chin LJ, Pelletier C, Blitzblau R, Tassi R, Paranjape T, Hui P, Godwin AK, Yu H, Risch H, Rutherford T, Schwartz P, Santin A, Matloff E, Zelterman D, Slack FJ, Weidhaas JB: A KRAS-variant in ovarian cancer acts as a genetic marker of cancer risk. Cancer Res 2010, 70:6509-6515.

16. Ratner ES, Keane FK, Lindner R, Tassi RA, Paranjape T, Glasgow M, Nallur S, Deng Y, Lu L, Steele L, Sand S, Muller R-U, Bignotti E, Bellone S, Boeke M, Yao X, Pecorelli S, Ravaggi A, Katsaros D, Zelterman D, Cristea MC, Yu H, Rutherford TJ, Weitzel JN, Neuhausen SL, Schwartz PE, Slack FJ, Santin AD, Weidhaas JB: A KRAS variant is a biomarker of poor outcome, platinum chemotherapy resistance and a potential target for therapy in ovarian cancer. Oncogene 2011, 30:1542-1550.

17. Grechukhina O, Petracco R, Popkhadze S, Massasa E, Paranjape T, Chan E, Flores I, Weidhaas JB, Taylor HS: A polymorphism in a let-7 microRNA binding site of KRAS in women with endometriosis. EMBO Mol Med 2012, 4:206-217.

18. Zhang W, Winder T, Ning Y, Pohl A, Yang D, Kahn M, Lurje G, LaBonte MJ, Wilson PM, Gordon MA, Hu-Lieskovan S, Mauro DJ, Langer C, Rowinsky EK, Lenz HJ: A let-7 microRNA-binding site polymorphism in 3'-untranslated region of KRAS gene predicts response in wild-type KRAS patients with metastatic colorectal cancer treated with cetuximab monotherapy. Ann Oncol 2011, 22:104-109.

19. Sebio A, Paré L, Páez D, Salazar J, González A, Sala N, del Río E, Martín-Richard M, Tobeña M, Barnadas A, Baiget M: The LCS6 polymorphism in the binding site of let-7 microRNA to the KRAS 3'-untranslated region: its role in the efficacy of anti-EGFR-based therapy in metastatic colorectal cancer patients. Pharmacogenet Genomics 2013, 23:142-147.

20. Nelson HH, Christensen BC, Plaza SL, Wiencke JK, Marsit CJ, Kelsey KT: KRAS mutation, KRAS-LCS6 polymorphism, and non-small cell lung cancer. Lung Cancer 2010, 69:51-53.

21. Pharoah PDP, Palmieri RT, Ramus SJ, Gayther SA, Andrulis IL, Anton-Culver H, Antonenkova N, Antoniou AC, Goldgar D, Beattie MS, Beckmann MW, Birrer MJ, Bogdanova N, Bolton KL, Brewster W, Brooks-Wilson A, Brown R, Butzow R, Caldes T, Caligo MA, Campbell I, Chang-Claude J, Chen YA, Cook LS, Couch FJ, Cramer DW, Cunningham JM, Despierre E, Doherty JA, Dörk T, et al: The role of KRAS rs61764370 in invasive epithelial ovarian cancer: implications for clinical testing. Clin Cancer Res 2011, 17:3742-3750.

22. Kjersem JB, Ikdahl T, Guren T, Skovlund E, Sorbye H, Hamfjord J, Pfeiffer P, Glimelius B, Kersten C, Solvang H, Tveit KM, Kure EH: Let-7 miRNA-binding site polymorphism in the KRAS $3^{\prime} U T R$; colorectal cancer screening population prevalence and influence on clinical outcome in patients with metastatic colorectal cancer treated with 5-fluorouracil and oxaliplatin +/- cetuximab. BMC Cancer 2012, 12:534.

23. Sha D, Lee AM, Shi Q, Alberts SR, Sargent DJ, Sinicrope FA, Diasio RB: Association study of the let-7 miRNA-complementary site variant in the 3 ' untranslated region of the KRAS gene in stage III colon cancer (NCCTG N0147 Clinical Trial). Clin Cancer Res 2014, 20:3319-3327.

24. Lee LJ, Ratner E, Uduman M, Winter K, Boeke M, Greven KM, King S, Burke TW, Underhill K, Kim H, Boulware RJ, Yu H, Parkash V, Lu L, Gaffney D, Dicker AP, Weidhaas J: The KRAS-Variant and miRNA Expression in RTOG Endometrial Cancer Clinical Trials 9708 and 9905. PLoS One 2014, 9:e94167.

25. Wang W-Y, Chien Y-C, Wong Y-K, Lin Y-L, Lin J-C: Effects of KRAS mutation and polymorphism on the risk and prognosis of oral squamous cell carcinoma. Head Neck 2012, 34:663-666.

26. Li Z-H, Pan X-M, Han B-W, Guo X-M, Zhang Z, Jia J, Gao L-B: A let-7 binding site polymorphism rs712 in the KRAS $3^{\prime}$ UTR is associated with an increased risk of gastric cancer. Tumour Biol 2013, 34:3159-3163.

27. Pan X-M, Sun R-F, Li Z-H, Guo X-M, Zhang Z, Qin H-J, Xu G-H, Gao L-B: A let-7 KRAS rs712 polymorphism increases colorectal cancer risk. Tumour Biol 2014, 35:831-835.

28. Jin H, Liang Y, Wang $X$, Zhu J, Sun $R$, Chen P, Nie $X$, Gao L, Zhang L: Association between a functional polymorphism rs712 within let-7binding site and risk of papillary thyroid cancer. Med Oncol 2014, 31:221.

29. Kim M, Chen X, Chin $\sqcup$, Paranjape T, Speed WC, Kidd KK, Zhao H, Weidhaas JB, Slack FJ: Extensive sequence variation in the $3^{\prime}$ untranslated region 
of the KRAS gene in lung and ovarian cancer cases. Cell Cycle 2014, 13:1030-1040.

30. Sabarinathan R, Wenzel A, Novotny P, Tang X, Kalari KR, Gorodkin J: Transcriptome-wide analysis of UTRs in non-small cell lung cancer reveals cancer-related genes with SNV-induced changes on RNA secondary structure and miRNA target sites. PLoS One 2014, 9:e82699.

doi:10.1186/s13045-014-0084-2

Cite this article as: Kim and Slack: MicroRNA-mediated regulation of KRAS in cancer. Journal of Hematology \& Oncology 2014 7:84.

\section{Submit your next manuscript to BioMed Central and take full advantage of:}

- Convenient online submission

- Thorough peer review

- No space constraints or color figure charges

- Immediate publication on acceptance

- Inclusion in PubMed, CAS, Scopus and Google Scholar

- Research which is freely available for redistribution 